\title{
The Spanish Constitutional Court and the Multilevel Protection of Fundamental Rights in Europe; Matters Relating to ATC 86/2011, of 6 June ${ }^{\star 1}$
}

\author{
Mercedes Pérez Manzano ${ }^{2}$
}

\begin{abstract}
I. The case: an example of the issues posed by the multilevel protection of fundamental rights. II. Prior Spanish constitutional jurisprudence: Is it applicable in cases which apply European law? III. The questions posed by the Spanish Constitutional Court. IV. Other implicit questions. $V$. An added problem: The differing European standards of protection with regard to trials in absentia. VI. Counter arguments to the maintenance of a higher domestic standard and its costs. 1. The reasons. 2. The costs. VII. The possibility of maintaining a higher national standard. 1. An interpretation of Arts. 47 (2) and 48 (1) CFREU, which provide more extensive protection than that of the European Court on Human Rights. 2. Conditions for the legitimacy of the restriction of the right to a fair trial: Art. 52.1 CFREU. 3. Art. 53 CFREU as a general minimum clause. 4 The case law of the European Court of Justice permits the coexistence of different standards. 5. A different interpretation of the case: the conditions of legitimacy for the tacit waiver of the right to a defence. VIII. Epilogue.
\end{abstract}

\section{The case: An example of the issues posed by the multilevel protection of fundamental rights}

On 9 June 2011, the Spanish Constitutional Court called for a resolution from the European Court of Justice, for the first time, in ATC 86/2011 ${ }^{3}$. This Order sought a preliminary ruling regarding a decision by the Audiencia Nacional $-1^{\text {st }}$ Chamber, Order of 12 September 2008 - which authorized the surrender of an Italian citizen, requested through a European arrest warrant, in order to serve a sentence which had been handed down in absentia. With this request, the Spanish Constitutional Court satisfied the complaints, submitted by a significant portion of

\footnotetext{
* Text accepted: July 2012.

${ }^{1}$ Order of the Spanish Constitutional Court (Auto del Tribunal Constitucional español), henceforth ATC.

${ }^{2}$ Professor of Criminal Law, Universidad Autónoma de Madrid

${ }^{3}$ See the commentaries of this Order made by Andrés Sáenz de Santamaría, P., Un nuevo paso en el diálogo judicial europeo: el Tribunal Constitucional español recurre al reenvío prejudicial, Homenaje a Ruiz-Jarabo, (press); Arroyo Jiminéz, L., Sobre la primera cuestión prejudicial planteada por el Tribunal Constitucional. Bases, contenido, consecuencias, WP IDEIR n ${ }^{\circ}$ 8, 2011, Papeles de Derecho Europeo e Integración Regional, and Indret 4/2011; Arias, J.M., Sobre las cuestiones prejudiciales planteadas en el auto del Tribunal Constitucional de 9 de junio de 2011 sobre la orden de detención europea, La ley n 7726, 31 of October 2011; Gippini, E., ¿Fin de la "autarquía jurídica" o preludio de un conflicto anunciado?. El primer reenvío prejudicial del Tribunal Constitucional, Gaceta Jurídica de la Unión Europea y de la Competencia, n 23, 2011; Revenga, M., Rectificar preguntando. El Tribunal Constitucional acude al Tribunal de Justicia (ATC 86/2011, de 9 de junio), Revista Española de Derecho Europeo (REDE) n ${ }^{\circ} 41$, 2012, pp. 135 et seqq.; Torres, A., Constitutional Dialogue on the European Arrest Warrant: The Spanish Constitutional Court knocking on Luxembourg's Door. Spanish Constitutional Court Order of 9 June 2011, European Constitutional Law Review, 8, 2012, 105-127.
} 
its members and of the authors ${ }^{4}$, for contributing to the dialogue between Courts in those cases in which the multilevel protection of fundamental rights creates interpretational differences regarding the content and scope of those rights.

The Constitutional Court posed three questions to the European Court of Justice related to the interpretation of the Framework Decision on the European arrest warrant as laid down in Council Framework Decision 2009/299/JHA, of 26 February, and related to articles 47 II, 48.2, 51, 52, and 53 of the Charter of Fundamental Rights of the European Union ${ }^{5}$. In order to better understand the questions posed, we must take into account the background.

The petitioner, seeking constitutional protection, was sentenced in absentia by a Court in Ferrara (Italy) after requesting his extradition from Spain in order to try him for the offence of fraudulent bankruptcy. The Audiencia Nacional authorized the extradition in 1996, but the requested person was never surrendered to Italy due to his disappearance, despite having paid the bond set by the Court. Under the given circumstances, the Court in Ferrara declared the defendant in contempt of court and proceeded to try him in absentia, ultimately finding him guilty of the offence of fraudulent bankruptcy and sentencing him to ten years in prison, a sentence which was later confirmed by higher courts. Years later, the Court in Ferrara again requested the surrender of the sentenced person from Spain in order to serve his prison sentence, this time under the new European legislation, the European arrest warrant Framework Decision. The Audiencia Nacional authorized the unconditional surrender in an Order of 12 September 2008. This is the Order which was then challenged before the Spanish Constitutional Court, in which the plaintiff held that the Audiencia Nacional had violated his right toa process with full guarantees by not demanding that Italy guarantee that the sentenced person has an opportunity to

\footnotetext{
${ }^{4}$ See the Dissenting opinions of the Justices Rodríguez-Zapata and Pérez Tremps to Spanish Constitutional Court Judgement (STC henceforth) 199/2009, of September 28. In the doctrine, among others, Ferreres, V., El juez nacional ante los derechos fundamentales europeos. Algunas reflexiones en torno a la idea de dialogo, en Carrillo/López (coord..), La Constitución Europea, Actas del III Congreso de la Asociación de constitucionalistas de España, Valencia, Tirant lo blanc, 2006, pp. 82 et seq.; de la Quadra-Salcedo Janini, T., El encaje constitucional del nuevo sistema europeo de detención y entrega (reflexiones tras la STC 177/2006), Revista Española de Derecho Constitucional (REDC) $\mathrm{n}^{\circ}$ 78, 2006, pp. 277 et seq., 292 et seqq.; Iruruzun, I./Mapelli, C. Orden europea de detención y Constitución. (Comentario a la Sentencia del Tribunal Constitucional 177/2006, de 5 de junio), Noticias de la Unión Europea, $n^{\circ}$ 282, 2008, pp. 15 et seq., 27; Izquierdo Sans, C. (Conflictos entre la jurisdicción comunitaria y la jurisdicción constitucional española (en materia de derechos fundamentales), Revista de Derecho Europeo (RDE), 34, 2010, pp. 193 and et seq.; Rodríguez Horcajo, D., Derecho Europeo y Derecho nacional: dos piezas (a veces) dificiles de encajar. Comentario a la Sentencia del Tribunal Constitucional 199/2009, de 28 de septiembre, Revista General de Derecho Penal (RGDP), 14, 2010, p. 15; Torres Pérez, A., Euroorden y conflictos constitucionales: A propósito de la STC 199/2009, de 28-9-2009, REDE, n 35, 2010, pp. 441 et seq., pp. 465 et seq.; Fontannelli, F., A comment on Tribunal Constitutional's judgement $n^{\circ} 199 / 2009$ and Czech Constitutional Court's judgement $n^{\circ}$ 29/1999. How interpretation techniques can shape the relationship between constitutional courts, en Stals Research Paper 1/2010. Even the Spanish Constitutional Court seemed to support this avenue for the resolution of problems between the Constitution and the Charter of Fundamental Rights in the European Union in the Declaration from the Constitutional Court (henceforth DTC) $1 / 2004$. Holding that those who must make use of the question for a preliminary ruling are common courts, more specifically the Audiencia Nacional in this case, Álvarez-Ossorio, F, Derechos y garantías en el espacio europeo de libertad, seguridad y justicia, en Ugartemendia/Jáuregui, Derecho Constitucional Europeo, Actas del VIII Congreso de la Asociación de constitucionalistas de España, Tirant lo blanc, Valencia, 2011, p. 423.

${ }^{5}$ Henceforth CFREU.
} 
apply for a retrial of the case and to be present at the judgement. Before handing down the judgement, the Constitutional Court decided to refer a question for a preliminary ruling to the European Court of Justice in ATC 86/2011, of 9 June 2011.

Despite the fact that the sentenced person was not present at the trial in which he was convicted, the background of the case as detailed in ATC 86/2011 reflects that the defendant freely designated legal defence, that notification of proceedings were delivered to his legal counsellor, and that this same legal counsellor acted in his defence; it is also reflected, however, that the defendant maintained that he had revoked the mandate given to this legal counsellor during the appeal phase and named new legal counsellors, even though the courts continued delivering notifications to the former. The Audiencia Nacional held that, the mandate of the initial legal counsellors had not been revoked and that they had, indeed, acted in defence of the accused person in all instances.

This case, therefore, is similar to others the Spanish Constitutional Court has heard regarding which standard of protection for the right to due process is applicable when examining foreign judgements, in which a sentence has been handed down in absentia, and thereby, according to Spain's legislation and constitutional culture, thus violating the right to a due process (Art. 24.2 Spanish Constitution). In these cases, the Spanish standard of protection for the right is higher than the Italian standard, and, furthermore, the judgements, which authorize surrender, reflect European law, which applies the principle of mutual recognition of judicial decisions. The fundamental questions are, therefore, whether the Constitutional Court is able to consider the eventual violation of the rights of the requested person, or whether this may only be evaluated by the State which has requested the surrender, and, as the case may be, by the European Court on Human Rights, as well as which standard of protection should be applied: that of Italy, that of Spain, that of the European Convention on Human Rights, or an intermediate standard.

\section{Prior Spanish constitutional jurisprudence: Is it applicable in cases which apply European law?}

The Spanish Constitutional Court has faced the question of different standards of protection for a fundamental right, where the Spanish standard is the highest, with regard to requests for extradition ${ }^{6}$. In these cases, the Spanish Constitutional Court has produced the doctrine of the indirect violation of the absolute content of a fundamental right. In accordance with this doctrine it is possible that a Spanish court which surrenders an individual to another State may violate the requested

\footnotetext{
${ }^{6}$ The Constitutional Court was faced with the problem early on in its mandate related to the respect of foreign criminal decisions. In terms of extradition, from SSTC 11/1983, of 21 February; 13/1994, of 17 January; 141/1998, of 29 June; 147/1999, of 4 August; 91/2000, of 30 March; the problem, however, has arisen in the case of the approval and recognition (via exequatur) of foreign judicial decisions, among others, in STC 43/1986, of 15 April; 54/ 1989, of 23 February; 132/1991, of 17 June.
} 
person's fundamental right in an indirect way if the issuing State's judgements, on which the detention order is based, have violated the "absolute content" of the alleged right because the Spanish court would have contributed to the damage of said fundamental right or, at least, to its exhaustion. With the doctrine of the absolute content of fundamental rights, the Spanish Constitutional Court attempted to find a formula which would not impose the higher domestic standard upon other States with which they came into contact through the recognition of the domestic effects of their judicial decisions - via exequatur or extradition -. Thus, they attempted to establish a common standard of fundamental rights which would be valid for all States. Therefore, in spite of the extreme positions which stipulate either strict conformity with the full national standard or a complete absence of control, the Spanish Constitutional Court opted for an intermediate position, akin to the "public order" clauses set forth in international law ${ }^{7}$.

The doctrine regarding the indirect violation of the absolute content of a fundamental right is based on the jurisprudence of the European Court on Human Rights from the 1989 Soering case. It was initially harshly criticized by Spanish doctrine $^{8}$. It seemed, however, to gain acceptance when it was used to examine the judgements handed down during extradition proceedings in countries such as Turkey, Albania, Venezuela, Peru, and other non-member States of the European Union ${ }^{9}$. Current criticism has centred on whether the Constitutional Court may apply this theory to analyse the constitutionality of decisions handed down in European Union countries, especially decisions pursuant to the European arrest

${ }^{7}$ STC 91/2000, of 3 March, Conclusions of Law (CL henceforth) 7 and 8. With regard to this question, see the author's work, Ius puniendi, fronteras y derechos fundamentales: un modelo constitucional de extradición, monografías de la Revista Aragonesa de Administración Pública, 2003, número monográfico VI: Ciudadanía e Inmigración, 2003, pp. 371 et seq.; La extradición: una institución constitucional, en Revista de Derecho Penal y Criminología (RDPyC) núm. 2 extraordinario, 2004, pp. 213 et seq.; El control constitucional de la extradición y de la orden europea de detención y entrega, en Casas/Rodríguez-Piñero, Comentarios a la Constitución española, XXX Aniversario, Fundación Wolter Kluwers, 2009, pp. 245 et seq.. Even though it is based on the doctrine of the European Court on Human Rights Judgement (henceforth ECHR) from the Soering v. UK case, of 7 July 1989, the theory of the absolute content of a fundamental right is connected to the doctrine of the German Constitutional Court with regard to extradition which also determines that the standard of reference is not the full domestic standard, but rather that of "public order". Regarding the German jurisprudence Lagodny, O., in Schomburg/Lagodny/Gléa/Hackner, Internationale Rechtshilfe in Strafsachen, 4th ed., 2006, § 73, 7 et seq.; Nieto Martin, A., [Kadi (STJUE de 3 de septiembre de 2008) y sus consecuencias para el Derecho penal del Consejo de Seguridad de Naciones Unidas y el Derecho penal de la Unión europea, in RGDP, $\mathrm{n}^{\circ}$ 10, 2008], who sets this thesis within the framework of the doctrine on European public order; see also Nieto Martin, A., El concepto de orden público como garantía de los derechos fundamentales en la cooperación penal internacional, en Díez-Picazo/Nieto, Los derechos fundamentales en el Derecho penal europeo, Civitas-Thomson, Navarra, 2010, pp. 453 et seqq., p. 473.

${ }^{8}$ See Dissenting opinions of STC 91/2000. Rey Martínez, F., El problema constitucional de la extradición de condenados en contumacia. Comentario de la STC 91/2000 y concordantes, en Teoría y realidad constitucional, $\mathrm{n}^{\circ}$ 5, 2000 , pp. 289 et seqq., 313 et seqq.; Torres Muro, I., Enseñar al que ya sabe. Las extradiciones ante el Tribunal Constitucional (STC 91/2000), Repertorio Aranzadi del Tribunal Constitucional, no 10, 2000, pp. 1859 et seqq.; Bellido, R., La condena en rebeldía en el proceso español de extradición pasiva, REDC n 57, 1999, pp. 285 et seqq. (a favor de la doctrina constitucional). Of all of the criticims made, the most far-reaching, in the author's opinion, is that featured in the individual dissenting opinion of Justice Cruz Villalón to STC 91/2000 (president of the Constitutional Court at that time), concerning the debatable nature of the notion that the presence of the accused person is a part of the absolute content of the right to a fair process, including its disassociation with his or her procedural conduct, as well as the obligation to use conditional surrender as a means of disputing the decision.

${ }^{9}$ For criticism of the application of the Soering doctrine in the European framework see Fletcher, M./Löof R./ Gilmore, B., EU Criminal Law and Justice, Elgar European Law, 2008, p. 125. 
warrant which are based on the principle of mutual recognition of judicial decisions. This is because, it is said ${ }^{10}$, that, in this case, the solution handed down by the Spanish Constitutional Court does not fit with European law: the doctrine of the Spanish Constitutional Court is at odds with the organization system of legal sources (national and European Law), and specifically, with the principle of primacy of European law and therefore, also, with the principle of mutual recognition of judicial decisions that is the linchpin of legal cooperation on penal matters in the European Union. This doctrine has become problematic, additionally, in that it impedes the uniform application of European Law and in that it should be, not the Spanish Constitutional Court, but the European Court of Justice who determines its uniform interpretation. Following the debate as to the application of a national standard to European arrest warrant resolutions, certain important alternatives have arisen: is it legitimate to reduce the national standard for the protection of fundamental rights in the interest of achieving European objectives ${ }^{11}$ ? Or, should fundamental rights set the limits on European objectives ${ }^{12}$ ? We must not only deal with the questions themselves, but also to what degree national constitutional courts may examine the adequacy of European law or national legislation which implements European law, in relation to fundamental rights, a question which cannot be easily answered given that there is no clear consensus among Member States in favour of rejecting the intervention of the national constitutional courts ${ }^{13}$.

\footnotetext{
${ }^{10}$ See Dissenting opinions of Justices Rodríguez-Zapata and Pérez Tremps to STC 199/2009, of 28 September.

${ }^{11}$ In the debate concerning whether the European Court of Justice can establish itself in a Constitutional Court, in a Court on Human Rights, it is noted that its competency is not absolute in terms of fundamental rights and this has caused a reduction in the content of rights, a necessary loss to achieve European objectives. Regarding the question as to whether the objectives of the "economic community" (achieve a single market, a union of currency and economy) have permeated the understanding of fundamental rights see Waelbroeck, M., La Cour de Justice et la Convention Européenne des droits de l'homme, Cahiers de Droit Européen, no 5-6, 1996, pp. 549-553; Biglino, P., ¿De qué hablamos en Europa cuando hablamos de Derechos Fundamentales?, REP, n 97, 1997, pp. $92-95$ et seq.; Saiz Arnaiz, La apertura constitucional al Derecho Internacional y Europeo de los derechos humanos. El art. 10.2 de la Constitución española, Consejo General del Poder Judicial, Madrid, 1999, pp. 180 et seq.; O’Neill, A. /Cappel, J. The European Court of Justice Taking Rights Seriously?, EUI Working Paper, law N ${ }^{\circ}$ 92/21, European University Institute, Florencia, p. 49.

12 The Advocate-General Cruz Villalón in his General Conclusions, of 6 June 2010, held a similar opinion in the I. B. case, which gave rise to the Judgement, of 21 October 2010, Fourth Chamber, C-303/09, in affirming that fundamental rights can limit mutual recognition of judicial decisions, though it should be nuanced that in the analyzed case the protection of the right did not oppose the objectives of European legislation. This question is all the more relevant when considering that the principle of mutual recognition of judicial decisions has meant "a equalization, on the lower level of protection, of procedural guarantees" in the European Union, see Bot, S., Le mandat d'arret européen, Ed. Larcier, Bruxelles, 2009, p. 574.

${ }^{13}$ Regarding the question as to what court has the best conditions to guarantee fundamental rights in Europe, and making out for a case for the European Court on Human Rights, Cruz Villalón, P., Unos derechos, tres tribunales, in Las transformaciones del Derecho del trabajo en el marco de la Constitución española: estudios en homenaje al profesor Rodríguez-Piñero y Bravo-Ferrer (Casas y otros, coord.), 2006, pp. 19 et seq.. As we know, European legislation concerning the European arrest warrant and implementing legislation has given rise to various pronouncements from the German, Polish, Czech, and Cyprus Constitutional Courts. The German Court has been the most radical given its ruling of the German law on implementation as unconstitutional. Though the grounds for dispute differ, these cases show that the way of protecting fundamental rights in the framework of mutual recognition of judicial decisions presents many rough edges. Concerning these decisions from the Constitutional Courts, see, among others, Mitsilegas V., Eu Criminal Law, Hart Publishing, Oxford, 2009, pp. 133 et seq. German Constitutional Court Judgements, BVerfGE, 37, 271 (Solange I), BVerfGE 73, 339 (Solange II), BVerfG. Urt. V. 30. 06. 2009; Italian Constitutional Court Judgement of 13 April 1989. More recently see BVerfGE 1 of 2 March 2009 ruling the German law on implementation of the Directive unconstitutional; also the judgement from the Romanian Constitutional
} 
Against the backdrop of this European-constitutional debate and the controversy of trials in absentia, the question has been continually posed to the Spanish Constitutional Court, always obtaining the same response. According to the Spanish Constitutional Court, the jurisprudence related to the indirect violation of the absolute content of fundamental rights is applicable to decisions which authorize surrender in accordance with domestic law implementing European arrest warrant legislation. It is also particularly applicable the condition of a retrial in the State of destination for surrender, if the requested person has been sentenced in absentia for a serious offence, because it is a requirement of the absolute content of the right to a process with full guarantees ${ }^{14}$ (Art. 24.2 SC). As a result, the Spanish Constitutional Court has ruled, on numerous occasions, that the right to a process with full guarantees, as established in Art. 24.2 SC, had been violated where the Audiencia Nacional had not established the above-cited condition for the requested surrender, according to Spanish law implementing European arrest warrant legislation ${ }^{15}$.

\section{The questions posed by the Spanish Constitutional Court}

The reiteration of the constitutional doctrine until the Judgement of the Spanish Constitutional Court (STC) 199/2009 of 28 September does not provide any clear indication of a change of course. However, the Constitutional Court decided to refer a question to the European Court of Justice for a preliminary ruling, given the importance of the root issue - the articulation of the protection of fundamental rights in the multilevel system in Europe - and given that the modification to the legislation regarding the European arrest warrant and the emergence of the Charter of Fundamental Rights of the European Union had altered the regulatory framework under which previous cases ${ }^{16}$ where judged. The following questions have been posed:

In relation to the interpretation of Art. 4 a.1 of Council Framework Decision 2002/584/JHA, of 13 June, concerning the European arrest warrant as amended in 2009, the Constitutional Court put forward the question as to whether, even though this provision includes only the possibility to refuse to execute an order in certain situations, it also prohibits conditional surrender hinging on the possibility for a retrial of the requested person under the same circumstances. To this end, the Court

Court, of 8 October 2009 (S. 1258), which ruled that the principles of the cited directive were contrary to the right to privacy pursuant to Art. 8 ECHR.

${ }^{14}$ Among others SSTC $177 / 2006$, of 5 June and 199/2009, of 28 September.

15 SSTC 177/2006, of 5 June and 199/2009, of 28 September. Irurzun, I./Mapelli, C., Noticias de la Unión Europea, no 282, pp. 15 et seqq.; de la Quadra-Salcedo Jannini, T., REDC nº 78, 2006, pp. 277 et seq. Cedeño, M., Vulneración indirecta de derechos fundamentales y juicio en ausencia en el ámbito de la orden europea de detención y entrega. A propósito de la STC 199/2009, de 28 de septiembre, en RGDE 20, 2010, pp. 8 et seqq.; Rodríguez Horcajo, D., RGDP, 14, 2010; Torres Pérez, A., REDE, n 35, 2010, pp. 441 et seqq.

${ }^{16}$ Concerning the specific requirements to be met to refer a question Dissenting opinion of Justice Pérez Tremps to ATC 86/2011 y Andrés Sáenz de Santamaría, P., Un nuevo paso en el diálogo judicial europeo: el Tribunal Constitucional español recurre al reenvío prejudicial, in Homenaje a Ruiz-Jarabo, (press). 
has indicated that Art. 1.3 of the aforementioned Framework Decision may be of significant assistance ${ }^{17}$.

In the event that the response affirmed that European law prohibited conditional surrender, the Constitutional Court puts forward a second question as to whether the aforementioned Art. 4 a.1 is compatible with the requirements for the rights to an effective remedy and to a defence as guaranteed in Arts. 47 II and 48.2 CFREU $^{18}$, which, in accordance with Art. 53, may be interpreted in light of the European Convention on Human Rights and the common constitutional traditions among Member States.

In the event that the response affirms the compatibility of Art. 4 a.1 of Framework Decision 2002/584/JHA with Arts. 47 II and 48.2 CFREU, the Court puts forward a final question as to whether Art. 53 CFREU allows States to pose the condition, which consists of giving the requested person the opportunity to apply for a retrial.

\section{Other implicit questions}

Even though these are the expressly raised questions, there are a number of critical questions, the resolution of which is essential to the configuration of fundamental rights in the European Union.

The mention of Art. 1.3 FD 2002/584/JHA is critical $^{19}$ given that a number of European States, based on this provision, have incorporated into their national legislation an "exception clause" in cases in which the fundamental rights of the requested person have been violated despite the fact that the violation of fundamental rights does not explicitly appear as grounds for refusal to execute an arrest warrant in the articles of the Framework Decision. For example, Art. 4.5 of the Belgian Law, of 19 December 2003, establishes that the execution of a detention order shall be refused "where there are serious grounds to believe that the execution of the arrest warrant will cause a violation of the fundamental rights of the affected person, as referred to in Article 6 of the Treaty on European Union" ${ }^{\text {20 }}$. It has even

\footnotetext{
${ }^{17}$ Art. 1.3. "This Framework Decision shall not have the effect of modifying the obligation to respect fundamental rights and fundamental legal principles as enshrined in Article 6 of the Treaty on European Union".

${ }_{18}$ Art. 47 II CFREU states that "Everyone is entitled to a fair and public hearing within a reasonable time by an independent and impartial tribunal previously established by law. Everyone shall have the possibility of being advised, defended and represented". Art. 48.2 CFREU also establishes that "Respect for the rights of the defence of anyone who has been charged shall be guaranteed".

${ }^{19}$ See Conclusions in Law (CL) 5.c), ATC 86/2011 and Arroyo Jiménez, L., Indret 4/2011, p.11.

${ }^{20}$ Section 21 of the 2003 United KingdomExtradition Act includes a similar clause, which forces judges to examine if "the extradition of a person is compatible with the rights in the Convention within the framework of the Human Rights Act of 1998." Concerning the question Vennemann, N., The European Arrest Warrant and its Human Rights Implications, en Zeitschrift für ausländisches öffentliches Recht und Völkerrecht (ZaöVR) 63, 2003, p. 115; Fletcher, M./Lööf, R./Gilmore, B., EU Criminal Law and Justice, Elgar European Law, 2008, pp. 122 et seqq. Also Art. 73.2 German Implementing Law of EAW of 20 July 2006 (BGBl, I, 1721). To see other legislation, Vernimmenvan Tiggelen, G./Surano, L./Weyembergh, A., The future of mutual recognition in criminal matters in the European Union, IEE-Université de Bruxelles, 2009, pp. 16, 181 et seq., 224. The 2005 report from the Commission pointed out that 2-3 Member States had decided to introduce the violation of fundamental rights as grounds for refusal to cooperate and remind us that said grounds must only be invoked in exceptional circumstances. Presently, there is a
} 
been argued that, though these grounds do not appear explicitly among those laid down for the refusal to surrender a requested person, a general exception can be found implied in point 12 of the Recital and in Article 1.3 of the Framework Decision $^{21}$. Use of this clause has become widespread, appearing explicitly in all legislation, which deals with the principle of mutual recognition of judicial decisions $^{22}$. More specifically, it has been incorporated into the very Framework Decision, which attempts to establish a unified concept of trials in absentia, thereby reinforcing the importance of the right to the defence to this field. The Decision goes so far as to mention it specifically. Council Framework Decision 299/2009, JHA, in Art. 1.2 establishes: "This Framework Decision shall not have the effect of modifying the obligation to respect fundamental rights and fundamental legal principles as enshrined in Article 6 of the Treaty, including the right to defence of a person subject to criminal proceedings, and any obligations incumbent upon judicial authorities in this respect shall remain unaffected."

The interpretation of these clauses is critical to practical application given the bearing they have on the European arrest warrant. In 2006, based on domestic law, Belgium refused to surrender a requested person to Austria on the grounds of suspicion of a potential violation of the right to freedom, to the presumption of innocence and to an impartial tribunal ${ }^{23}$. In 2005, Holland also refused to surrender a requested person to Spain on the grounds of a violation of the right to a process with undue delay ${ }^{24}$. Bulgaria even refused to surrender a requested person to Romania, without applying any specific domestic legal provision, on the basis of a violation of fundamental rights in the Judgement, of 27 February $2007^{25}$. A more recent application of these general clauses occurred in the Stuttgart High Court decision, of 25 February $2010^{26}$, in which, when presented with an arrest warrant issued by Spain in order to try the defendant for the offence of drug trafficking

precept, similar to that which is laid out in Art. 1.3, in all legislation based on the principle of mutual recognition of judicial decisions.

${ }^{21}$ See the author's work Ius puniendi, fronteras y derechos fundamentales: un modelo constitucional de extradición, en Monografias de la Revista Aragonesa de Administración Pública, Inmigración y Ciudadanía, pp. 413 et seq.

${ }^{22}$ See Nieto Martín, A., El concepto de orden público como garantía de los derechos fundamentales en la cooperación penal internacional, en Díez-Picazo/Nieto, Los derechos fundamentales en el Derecho penal europeo, Civitas-Thomson, Navarra, 2010, pp. 453 et seq., 455, 476.

${ }^{23}$ See the Judgement from the Indictment Chamber, of 8 December 2006, cited by Weyembergh, A. /Santamaria, La reconnaissance mutuelle en matière pénale en Belgique, en Vernimmen-van Tiggelen, G./Surano, L./Weyembergh, A., The future of mutual recognition p. 76.

${ }^{24}$ Judgement, of 1 July 2005, from the District Court of Amsterdam, cited by van Ballegooij, W., Vernimmen-van Tiggelen, G. /Surano, L./Weyembergh, A., The future of mutual recognition p. 409.

${ }^{25}$ Chinova, M./Assenova, M., L' application du principe de la reconnaissance mutuelle en matière pénale en Bulgarie, en Vernimmen-van Tiggelen, G./Surano, L./Weyembergh, A., The future of mutual recognition p. 95. See also de Amicis, G., (La reconnaissance mutuelle et la mise en oeuvre du mandat d'arret européen dans l'ordre juridique italien, en Vernimmen-van Tiggelen, G./Surano, L./Weyembergh, A., The future of mutual recognition, p. 332) regarding cases in which the Italian Court of Cassation examined the violation of the fundamental rights related to the EAW in Italy.

${ }^{26}$ Asunto 1246/09. There is a commentary from Pérez Fernández, P., La orden de detención y entrega y el principio de proporcionalidad de las penas. Comentario a la Sentencia del Tribunal Superior de Justicia de Stuttgart, de 25 de febrero de 2010 (Asunto número 1246/09), RGDP 13 (2010). See also Vogel, J., Introduction to the ruling of the Higher Regional Court of Stuttgart of 25 February 2010 - The proportionality of a European arrest warrant, New Journal of European Criminal Law, 2010, 2, pp. 145 et seq.. 
which carried a punishment of three to nine years in prison, the Court considered the eventual violation of the principle of proportionality between offences and of the punishment as currently set out in Art. 49.3 CFREU ${ }^{27}$. Without prejudice to the fact that the Court ruled that this principle, understood as it is in the standard of European public order, was ultimately not violated, this judgement is further evidence that Member States continue utilizing this clause as grounds for general refusal, i. e. as if it were included among the grounds for refusal to recognize a judicial decision.

This question, previously raised in the I. B. case, C-306/09, was not answered by the European Court of Justice due to the fact that it was not vital to the resolution of the case and therefore, remains outstanding. Thus, a response from the Court of Justice is all the more urgent. The acknowledgement of this clause as a clause of "European public order", in the area of fundamental rights, underscores its effectiveness, thereby influencing the meaning and scope of the principle of mutual recognition and confirming that despite statements made in the Recital of the Framework Decision, mutual recognition does not imply, to date, the automatic application of a judicial decision in a European Member State without certain control $^{28}$.

Secondly, in order to respond to the question of validity, as set forth in the second question, it is necessary for the Court of Justice to first of all rule on the scope and interpretation of the rights enshrined in Arts. 47 II and 48.2 CFREU, thereby implying that both the question of the interpretation of the Charter concerning the content of the cited rights and the question of the validity of the Framework Decision are at the core of this matter.

On the other hand, the third question implicitly poses the question, as to whether Art. 53 CFREU allows for the validation of a higher national standard. A positive answer to the third question constitutes a form of validation for the Spanish Constitutional Court with regard to their course of action in having a higher standard than that of Europe.

Lastly, if Framework Decision 2009/299/JHA has diminished the content of the right to a fair trial with full guarantees in comparison to that set forth in Framework Decision 2002/584/JHA and in comparison to that established in the jurisprudence of the European Court of Justice, then one must also consider whether the restriction on this fundamental right was produced under the requisite conditions of legitimacy as laid down in Art. 52.1 CFREU, which establishes "Any limitation on

\footnotetext{
${ }^{27}$ It is a case regarding the offering of a $0.199 \mathrm{gr}$. bag of cocaine with a purity of $51.13 \%$ by a repeated offender with criminal cases in Spain as well as Germany and who was serving his sentence in Germany at the time.

${ }^{28}$ The automatic character of recognition is neither reflected in European legislation nor is it free of critics. See Schünemann, B., Europäischer Haftbefehl und der EU-Verfassungsentwurf auf schifer Ebene, Zeitschrift für Rechtspolitik, 2003, pp. 187 et seq.; Schünemann, B., Bürgerrechte ernst nehmen bei der Europäisierung des Straverfahrens, Strafverteidiger 2/2003, pp. 116 et seq.; de Hoyos, M., Armonización de los procesos penales, reconocimiento mutuo y garantías esenciales, pp. 42 y ss. pp. 70 et seqq., in De Hoyos (coord.), El proceso penal en la Unión Europea. Garantías esenciales, Lex Nova, Valladolid, 2008; Armenta, A., Aproximación al proceso penal en Europa: proceso penal europeo o europeización del proceso penal, en Revista General de Derecho Procesal, 22, 2010, pp. 24 et seqq., 28.
} 
the exercise of the rights and freedoms recognized by this Charter must be provided for by law and respect the essence of those rights and freedoms. Subject to the principle of proportionality, limitations may be made only if they are necessary and genuinely meet objectives of general interest recognized by the Union or the need to protect the rights and freedoms of others".

\section{An added problem: The differing European standards of protection with regard to trials in absentia}

The solution to cases of surrender of requested persons in order to serve sentences resulting from trials carried out in absentia is not a simple matter due to the fact that, in addition to the general difficulties, one must also take into account the fact that the difference between standards of protection within Europe is extremely broad. On the one hand, the Spanish standard is one of the most protective among European States, more so than that of the European Court on Human Rights since the unification of doctrine in the Sejdovic v. Italia Judgement, of 1 March 2006. The Spanish Constitutional Court believes that conditional surrender is a central part of the right to a due process without nuances as to the conditions or the circumstances under which the trial in absentia took place ${ }^{29}$, while the European Court on Human Rights provides a more nuanced explanation. However, the standard of protection set forth by the European Court on Human Rights is more protective than that which the European Union established in Council Framework Decision 2009/299/JHA, of 26 February $2009^{30}$.

In accordance with the jurisprudence of the Spanish Constitutional Court, any surrender of a requested person in order to serve a sentence delivered in a trial in absentia for a serious offence, violates the right to a process with full guarantees if the surrender of the requested person does not include the assurance that said person will have the right to apply for a retrial. The Spanish Constitutional Court makes no distinction with regard to the default of appearance by the defendant, nor the presence or lack thereof a legal counsellor. The Spanish Constitutional Court believes that the right of the defendant to be present in the hearing and to defend himself are elements of the absolute content of the right to a fair trial given that, in criminal proceedings, the right of the defendant to be present in the hearing is not merely a requisite of the principle of the adversarial system, but also a mechanism which makes the exercise of the right to defend oneself and answer

\footnotetext{
${ }^{29}$ See STC 91/2000, of 30 March, FFJ 12 et seq.

${ }^{30}$ This Framework Decision is entitled "thereby enhancing the procedural rights of persons and fostering the application of the principle of mutual recognition to decisions rendered in the absence of the person concerned at the trial" and its introduction altered all of the Framework Decisions concerned with the principle of mutual recognition and not solely those concerning the European arrest warrant. Despite the time frame set for its implementation, no modification to Spanish Ley 3/2003, of 14 March, regarding the European arrest warrant, has been carried out, to adapt it to the new European law. Regarding the differing standards for the right to a process with full guarantees in trials in absentia see Queralt Jiménez, A., La interpretación de los derechos: del Tribunal de Estrasburgo al Tribunal Constitucional, Centro de Estudios Políticos y Constitucionales, Madrid, 2008, pp. 335 et seq.; Cedeño, M., RGDE 20, 2010, pp. 8 et seqq., 10 et seq.; Torres Pérez, A., REDE, nº 35, 2010, pp. 441 et seqq., pp. 452 et seqq.
} 
accusations possible ${ }^{31}$. However, from the jurisprudence of the European Court on Human Rights, one can interpret that there is no violation of the right guaranteed in Art. $6.3 \mathrm{~d}$ ) of the European Convention on Human Rights and Fundamental Freedoms (henceforth ECHR) if the absence of the defendant in a trial is voluntary and he or she has indeed been defended in trial by a legal counsellor. Though there are many situations and nuances in this jurisprudence, one can hold that a violation of the right to a due process occurs under the following circumstances $^{32}$ :

If the defendant has not been personally notified of the trial or hearing and has not been made aware of court proceedings through other means.

If, having been properly notified of the trial, it cannot be established whether the defendant has unequivocally renounced his right to appear in court, without his or her waiver may be deduced from plain notification of the trial (ECHRJ FCB v. Italy, of 28 September 1991).

If, having been correctly notified of the trial, the defendant did not possess a legal counsellor of his or her choice or if the legal counsellor did not effectivey defend him or her. The right to legal defence cannot be restricted due to the mere reason of the defendant's absence, (ECHRJ Poitrimol v. France, of 23 November 1993, par. 35; Lala v. the Netherlands, of 22 September 1994, par. 27; Pelladoah v. the Netherlands, of 22 September 1994, par. 40).

And additionally, if national law fails to guarantee a retrial in the event of any of the prior circumstances (lack of awareness on the part of the defendant, lack of an unequivocal waiver of the right to appear in the Court, or lack of a legal counsellor of the defendant's choice).

European law concerning the European arrest warrant, in its first draft, in Council Framework Decision 2002/584/JHA, of 13 June, established, in Art. 5.1, the possibility that States could lay out conditions for the surrender of a requested person in cases in which the defendant "has not been summoned in person or otherwise informed of the date and place of the hearing which led to the decision rendered in absentia". As we have pointed out, this regulation conflicted with the jurisprudence of the European Court on Human Rights for two reasons. On the one hand, conditional surrender of the requested person is categorized as optional for Member States while, in accordance with the jurisprudence of the European Court of Human Rights, the condition should be compulsory in those cases in which the defendant does not appear at the trial due to a lack of notification or lack of awareness of the proceedings. If the optional nature of the condition attempts to salvage the legislative difference among European States, so that those which permit trials in absentia do not feel forced to establish an effective remedy and a conditional

\footnotetext{
${ }^{31}$ STC $91 / 2000$, of 30 March, FJ 13. Of all of the criticisms made, the most far-reaching, in the author's opinion, is that featured in the individual vote of Justice Cruz Villalón (president of the Constitutional Court at that time), concerning the debatable nature of the notion that the presence of the accused person is a part of the absolute content of the right to a fair process, including its disassociation with his or her procedural conduct, as well as the obligation of conditional surrender as a means of disputing the decision.

${ }^{32}$ See Cedeño, M., RGDE 20, 2010, pp. 10 et seqq.
} 
surrender, and although this is a traditional formula from the European Convention on Extradition, it is clear that the jurisprudence of the European Court on Human Rights illustrates that, under these conditions, the right to a fair trial is violated, and therefore, it does not seem appropriate that the European legislation does not adapt to the aforementioned standard, thereby demanding conditional surrender. On the other hand, Art. 5.1 of Framework Decision 2002/584/JHA allows conditional surrender only in cases where there is a lack of awareness of the trial; this eliminates the option of States to demand it in cases in which the defendant was not indeed defended by a legal counsellor, despite having been personally notified or informed through other official means during the proceedings.

The gap between the cited European Law and jurisprudence of the European Court on Human Rights has not been accounted for with the 2009 modification to Framework Decision 2002/584/JHA. In fact, it has widened as a result of Framework Decision 2009/299/JHA despite being based, it is said, on the jurisprudence of the Court at Strasbourg. This Framework Decision has substituted Art. 5.1 of the 2002 Framework Decision with a new article, 4 a.1, which establishes that:

"1. The executing judicial authority may also refuse to execute the European arrest warrant issued for the purpose of executing a custodial sentence or a detention order if the person did not appear in person at the trial resulting in the decision, unless the European arrest warrant states that the person, in accordance with further procedural requirements defined in the national law of the issuing Member State:

(a) in due time:

(i) either was summoned in person and thereby informed of the scheduled date and place of the trial which resulted in the decision, or by other means actually received official information of the scheduled date and place of that trial in such a manner that it was unequivocally established that he or she was aware of the scheduled trial;

and

(ii) was informed that a decision may be handed down if he or she does not appear for the trial;

or

(b) being aware of the scheduled trial, had given a mandate to a legal counsellor, who was either appointed by the person concerned or by the State, to defend him or her at the trial, and was indeed defended by that counsellor at the trial;

or

(c) after being served with the decision and being expressly informed about the right to a retrial, or an appeal, in which the person has the right to participate and which allows the merits of the case, including fresh evidence, to be re-examined, and which may lead to the original decision being reversed:

(i) expressly stated that he or she does not contest the decision;

or

(ii) did not request a retrial or appeal within the applicable time frame;

or

(d) was not personally served with the decision but: 
(i) will be personally served with it without delay after the surrender and will be expressly informed of his or her right to a retrial, or an appeal, in which the person has the right to participate and which allows the merits of the case, including fresh evidence, to be re-examined, and which may lead to the original decision being reversed;

and

(ii) will be informed of the time frame within which he or she has to request such a retrial or appeal, as mentioned in the relevant European arrest warrant".

This provision is conspicuously contrary to Spanish Constitutional jurisprudence $^{33}$, as is its lack of harmonisation with jurisprudence of the European Court on Human Rights self-evident. Not only are the same deficiencies, as were present in the first draft, present in the latter, but in this new draft, the standard for the right to a process with full guarantees has been reduced. On the one hand, the optional nature of the refusal to surrender in cases of incorrect notification or lack of awareness of the trial is maintained, and on the other hand, neither an unequivocal waiver of the right to appear in trial nor an unequivocal waiver of the right to appeal or to a retrial are necessary for the correct application of Art. $4 \mathrm{a} 1$. In Art. 4 a.1, if the defendant was aware of the trial or of the time frame for an appeal and did nothing, the Court may understand these inactions as a waiver of these rights. This is not compatible with the ECHRJ, in FCB v. Italy, of 28 August $1991^{34}$. Thirdly, the clearest cases of the incompatibility between Art. 4 a.1 and the jurisprudence of Strasbourg are those referred to in points a) and d). The first clause establishes that surrender cannot be refused if the defendant knew about the judicial proceedings, despite not being represented by a legal counsellor. This interpretation stems from the notion that awareness (point a) and a defence (point b) are not cumulative requisites as called for by the European Court on Human Rights. This is blatantly incompatible with the previously mentioned classic judgements and with the compilation of European jurisprudence laid out in the 2006 Sedjovic v. Italy Judgement. Finally, according to point (b) of Art. 4 a.1, proof of the intention to personally notify the requested person the decision without delay after surrender, is basis enough to prevent the executing State from refusing. This is, without a doubt, the clearest case of the application of the principle of mutual recognition among States as a limiting principle with regard to fundamental rights. Much has been written concerning the idea that, in the European Union, mutual recognition of judicial decisions is underpinned by the principle of mutual trust among States. The question, however, is whether we aren't mixing two considerably different matters: the principle of mutual trust governs the relations between EU States, while the relations between citizens and States should not be governed by this same principle. On the contrary, if the essence of fundamental rights is that they are rights, which

\footnotetext{
${ }^{33}$ Of the same opinion Izquierdo Sans, C., RDE 34, 2010, p. 219.

${ }^{34}$ It is a case in which Mr. F. C. B. was not personally notified of the decision because he was in police custody and the proceedings were confidential; in spite of actually being defended by a legal counsellor and one could argue that he was aware of the proceedings, it has been stated that there was no unequivocal waiver of the right to appear in the trial and defend himself. This case shows that the awareness of the trial and the defence by a legal counsellor are not sufficient to guarantee the right to a defence.
} 
defend the citizen against the State, the principle that governs their relations is, if not one of mistrust, one of control of the adequacy of the actions of the State with regard to fundamental rights.

In the face of this gap between European legislation and the standard of the fundamental rights in accordance with the European Convention on Human Rights and the jurisprudence of Strasbourg, it is worth remembering that the European Court on Human Rights ruled that States could not evade their obligations to protect the human rights for which they are responsible, pursuant to the European Convention, under the pretext of having acquiesced to the transfer of competencies to an international organization ${ }^{35}$. The European Court is basing its doctrine on some type of presumption of lawfulness or a justification of the European measures as to ensure a level of protection equivalent to that afforded by the European Convention; it is, however, not an irrefutable presumption. The European Court admits to evidence to the contrary and that it is in itself, competent to evaluate and punish the existence of insufficient protection ${ }^{36}$.

\section{Counter arguments to the maintenance of a higher domestic stan- dard and its costs}

The novelty, complexity, and transcendence of the questions posed do not afford any degree of foresight as to the response of the Court of Justice. If the dispute is resolved in favour of the application of a more protective standard, such as is the case in Spain, many problems will arise in terms of adjustment to the European legislation and principles.

\section{The reasons}

To begin with, in order to guarantee this standard, Spain has had to utilize conditional surrender in cases in which it was not set forth in European legislation and said conditions have, therefore, had the effect of restricting the applicability of the principle of mutual recognition of judicial decisions, an effect which appears contrary to the jurisprudence of the European Court of Justice, especially in its ruling on the Wolzenburg case, Judgement of 6 October 2009 ${ }^{37}$. Furthermore, despite the Conclusions of the I.B. Case (C-303/09), Advocate-General Cruz Villalón admitted that States could include a condition, which has not been established in European Law, in order to safeguard the fundamental rights of the requested person, stating that even though said condition might limit the principle

\footnotetext{
${ }^{35}$ Judgment of European Court of Human Rights (STEDH henceforth) of 6 February 1999, Matthews v. United Kingdom, 34; and Commission Decision of 9 January 1990, M.\&Co v. FR Germany.

${ }^{36}$ STEDH of 30 June 2005, Bosphorus v. Ireland, 155 et seq. Within this framework, States are not held responsible for the inappropriate protection of rights if they would have no discretion to implement and apply European Law, but they are held accountable in the opposite case. See Covolo, V., La judiciarisation de l'espace pénal de l'Union fut ... mais où se cache le juge pénal européen?, en Cahiers de droit européen 1, 2011, pp, 106 et seq., p. 140.

${ }^{37} \mathrm{C}-123 / 08,58$ and 59.
} 
of mutual recognition, the final result of the conditional surrender was not contrary to the ultimate objectives of the applied Framework Decision; it instead strictly complied with it and with the right to privacy and family privacy as recognized in Art.7 CFREU, pursuant to the Framework Decision. On the contrary, conditional surrender, based on a European arrest warrant, substantiated by decisions taken in absentia, results in a restriction of the scope of the principle of mutual recognition of judicial decisions, which, in theory, seems to go against the object of the European regulation which attempts to guarantee the free movement of judicial decisions.

Secondly, the maintenance of the Spanish standard is not easy for the Court of Justice because a restrictive interpretation of Art. 53 CFREU would not allow for this article to be considered a general safeguard of the highest standard of protection, be it national or European. This article establishes that: "Nothing in this Charter shall be interpreted as restricting or adversely affecting human rights and fundamental freedoms as recognized, in their respective fields of application, by Union law and international law and by international agreements to which the Union, the Community or all the Member States are party, including the European Convention for the Protection of Human Rights and Fundamental Freedoms, and by the Member States' constitutions." Given its wording, it seems to indicate that the object of this provision is to safeguard the national standard of protection, but only in nonEuropean areas, i. e. those areas in which the EU does not have competency, and thus in those spheres where conflicts do not arise. This precept does not mean, however, that in cases in which the provisions of the Charter come into conflict with the national standard in areas of EU competency, "the Constitutions of Member States" and their own standards of protection prevail. Ultimately, this precept does not include the principle of "favor libertatis" and its general scope 38 and therefore, it would not be possible to base the legitimacy of conditional surrender on it $^{39}$.

\section{The costs}

If the response from the Court at Luxembourg were to reject the possibility of maintaining the higher Spanish standard, the Spanish Constitutional Court would be faced with a difficult decision, given that it cannot continue placing conditions on the surrender of requested persons without committing a clear violation of its commitments to the European Union; it cannot, however, stop this practice without violating the Spanish Constitution either. In such circumstances, the Constitutional Court must either appeal to Declaration 1/2004, which reserves for Spain the right to have the last word ${ }^{40}$ on whether a European constitutional law is

\footnotetext{
${ }^{38}$ It has been stated that this clause only represents one source for establishing the precise level of protection that the EU requires for any given right and does not allow the higher standard to prevail, not even with regard to these competencies, see Martín y Pérez de Nanclares, Comentario al art. 53 de la Carta, in Mangas, A., Carta de derechos fundamentales de la UE, pp. 859 et seqq.

${ }^{39}$ Martín y Pérez de Nanclares, Comentario al art. 53 de la Carta, in Mangas, A., Carta de derechos fundamentales de la UE, pp. 859 et seqq.

${ }^{40}$ DTC $1 / 2004$, of 13 December, FJ 4.
} 
compatible with the Spanish system, or revise its Constitutional doctrine regarding the absolute content of the right to a process with full guarantees in the cases of trials in absentia, given that said content is determined by taking into account the content of the international Treaties in which Spain has taken part (Art. 10.2 SC). This includes the Charter on Human Rights of the European Union as well as the European Convention on Human Rights and Fundamental Freedoms and the jurisprudence of the European Courts of Justice and on Human Rights. The Constitutional Court must take into special account the jurisprudence of this last body given that the referrals in Union Law to the European Convention and the jurisprudence of Strasbourg have made it the "common denominator for the establishment of shared elements of interpretation in the minimum content thereof " ${ }^{\prime 1}$. In this case, however, the Constitutional Court must make it clear that reduction of the standard would only be effective ad extra and limited to application within the European legal framework. As a result, for the rest of the cases (domestic and international), it would be necessary to maintain the current higher standard, which, we must remember, is, in turn, a double standard: a full standard for domestic matters and a reduced standard (in terms of absolute content) for evaluating foreign decisions which claim validity in Spain. On a theoretical level, nothing would prevent the domestic standard from continuing at the same highly protective - full - level, nor would anything prevent Spain from continuing to apply the most protective standard when deciding as to the validity of foreign extradition rulings in terms of fundamental rights. In that case, what possibility does the more protective standard have of remaining in force if it is only applied on a domestic level or in order to decide on ad extra judgements from countries outside the European Union or from EU countries pursuant to non-EU legislation $^{42}$ ? In the author's opinion, it would be difficult to maintain the more protective standard even within a determined context, and therefore, the preeminent character of Union Law would probably cause a general reduction in the standard of penal guarantees on the domestic level in any case to which they were to be applied ${ }^{43}$.

In this case, a judgement such as the one previously mentioned, which granted primacy to the lower European standard and required Spain, de facto, to reduce its

\footnotetext{
${ }^{41}$ DTC $1 / 2004$, of 13 December, FJ 6.

${ }^{42}$ Regarding the "natural convergence" of rights in Europe, the difficulties of a duality of regimes due to the permeability of human rights and the chances that the standard set forth in the Charter on Fundamental Rights of the European Union will prevail over the others, see Mangas Martin, A., Artículo 51. Ámbito de aplicación, en Carta de Derechos Fundamentales, p. 814; regarding doubts that this convergence is occurring Rubio, F, Mostrar los derechos sin destruir la Unión. Consideraciones sobre la Carta de Derechos Fundamentales de la Unión Europea, REDC, 64, 2002, pp. 13 et seq., 35 and López Guerra, L., Derechos e Integración europea, in Ugartemendia/Jáuregui, Derecho Constitucional Europeo, Actas del VIII Congreso de la Asociación de constitucionalistas de España, Tirant lo blanc, Valencia, 2011, pp. 26 et seq.

${ }^{43}$ The Charter on Fundamental Rights of the European Union as one of the international treaties concerning rights and freedoms is a part of the international law to which Art. 10.2 SC refers in order to determine the content and scope of rights, and this reference is not limited to its application in the European sphere but rather a general scope, see Pérez Tremps, P. Las "Cartas" y los "Tribunales", en VVAA, Estudios sobre la Constitución Española, Homenaje al profesor Jordi Solé Tura, Cortes Generales, Madrid, 2009, vol. II, pp. 2002 et seq.
} 
standard of guarantees inherent in the right to a due process, would also place the European Court of Justice in a difficult situation. If the European Court of Justice ends up affirming the primacy of the European standard of fundamental rights despite its being lower than the national standard, this would result in difficulty in explaining its position in the Kadi case, Judgement of 3 September, $2008^{44}$, because, in this case, the Court defined its relation with the pronouncements of other international organs, in terms of fundamental rights, using the conclusions of Advocate-General Poaires, who held that the integration of the resolutions of the Security Council in Union Law could not involve "exceptions to the principles of liberty, democracy, respect for human rights and fundamental freedoms enshrined as a foundation in the Union in Art. 6.1 TEU." If this is so, the European Court of Justice must explain with what legitimacy and in what cases it opposes the reduction of the standard of fundamental rights ad extra and, at the same time, requires that Member States reduce their standards ad intra. In this case, it seems insufficient, moreover, to appeal exclusively to the logic of its competencies, to the principle of primacy of Union Law, or to the need to guarantee the mutual recognition of judicial decisions within the EU. When fundamental rights are at stake, none of these reasons provide sufficient legitimacy ${ }^{45}$. On the one hand, this is due to the fact that the European Union lacks competency in terms of fundamental rights, in spite including the Charter in its primary law framework, and also because requiring a State to reduce its standard of protection means assigning itself competencies which deal with fundamental rights ${ }^{46}$. On the other hand, the essence and the logic of the existence of fundamental rights is to set the limits of their legal use for public authorities, be it national or supranational, and therefore, the question is not whether fundamental rights must be sacrificed to achieve the recognition of judicial decisions within the European Union, but rather to what degree it is legitimate necessary and proportional - to place the mutual recognition of judicial decisions before fundamental rights. Finally, with special reference to Spain because we cannot forget the circumstances in the Spanish Constitution, which led to the drafting of Declaration 1/2004: Art. 94.1 establishes the need for prior authorization of the Parliament for entering into any treaty affecting the fundamental rights and duties established under Title 1, and Art. 95.1 establishes that the conclusion of an international treaty containing stipulations contrary to the Constitution shall require prior constitutional amendment. As is known, neither of these situations has occurred, nor has the Constitutional Court considered them necessary. Declaration $1 / 2004$ was drafted under the conception of complete compatibility of the national

\footnotetext{
${ }^{44}$ Kadi and Jusuf Al Baralaat International Foundation v. Council and Comission, joined cases C-402/05 P y C-415/05 P, Judgment Grand Chamber, of 3 September 2008 and C-309/06 P and C-403/06 P (Faraj Hassan y Ayadi) Judgment Court of Justice European Union (STJUE henceforth) of 3 December 2009. See Nieto Martin, A., Kadi (STJUE de 3 de septiembre de 2008) y sus consecuencias para el Derecho penal del Consejo de Seguridad de Naciones Unidas y el Derecho penal de la Unión europea, RGDP, nº 10, 2008.

${ }^{45}$ In fact the application of any of these criteria would have led to a different outcome of the Kadi case. See Nieto Martín, A., RGDP, n 10, 2008.

${ }^{46}$ Similarly Mangas, A., Carta de derechos, p. 815; Alonso García, R., Sistema jurídico de la Unión Europea, Civitas-Thomson, Navarra, 2a ed. 2010, p. 320; Izquierdo Sans, C., RDE 34, 2010, p. 203.
} 
standards with their European counterparts ${ }^{47}$. If the Constitutional Court was mistaken, and, as we attempt to show here, there are discrepancies between the European and national standards of protection for certain fundamental rights: Can the Constitutional Court rectify this discrepancy by modifying its jurisprudence, or should it be the citizens who democratically speak out to show their outrage at the persistence of an supranational institution who reduces their standard of fundamental rights protection?

\section{The possibility of maintaining a higher national standard}

The importance of these questions requires a calm response from the Court of Justice, which takes into account all possible arguments. Notably, the Court of Justice should consider the arguments advanced by the Spanish Constitutional Court which would allow for a different outcome and would open up the possibility of maintaining the higher Spanish standard and of continuing the practice of conditional surrender hinging on the opportunity for the requested person to apply for a retrial of the trial held in absentia.

\section{An interpretation of Arts. 47 II and 48.1 CFREU, which provide more extensive protection than that of the European Court on Human Rights}

A priori, the simplest way for Spain to maintain its Constitutional jurisprudence would be for the Court of Justice to rule that Art. 4 a.1 of Framework Decision 2002/584/JHA, 2009 version, violated the fundamental rights enshrined in Arts. 47 II and 48.2 CFREU, granting them greater scope and content than that provided in the right to a process with full guarantees by the jurisprudence of the European Court on Human Rights, as permitted in Art. 53.2 CFREU. If, on the contrary, the Court interpreted said articles as providing the same level of protection as that granted by the European Court on Human Rights, it would be of no use for this case. Even though the standard set forth by the European Convention on Human Rights in its interpretation by the European Court is higher than the standard of protection laid out in the 2009 Framework Decision, this finding would not affect the immediate case for which the Spanish Constitutional Court referred this question for a preliminary ruling, given that the sentenced person was aware of the trial and was indeed defended by a legal counsellor of his choice. Additionally, as has already been stated, in these cases the jurisprudence of the European Court on Human Rights does not confirm the violation of the right to a process with full guarantees.

\footnotetext{
47 The statement which holds that "In the unlikely case where, in the ulterior dynamics of the legislation of the European Union, said law is considered irreconcilable with the Spanish Constitution, ... could lead this Court to approach the problems which, in such a case, would arise... through the corresponding constitutional procedures" is unequivocal.
} 
An interpretation of Arts. 47 II and 48.2 CFRUE which provide more extensive protection than the European Court on Human Rights, could be supported by the Constitutional traditions common to Member States, which together with the European Convention on Human Rights and the jurisprudence of the European Court on Human Rights make up privileged interpretational criteria for setting the content of the rights laid out in the Charter ${ }^{48}$. R. Alonso Garcia warned ${ }^{49}$, parting from an analysis of Comparative Law, that the European Court of Justice enjoys broad room for manoeuvre for establishing the degree of protection provided in the Charter, without requiring an interpretation of the "common Constitutional traditions" in terms of a "least common denominator". On the one hand, in the Explanations, it states that with reference to common Constitutional traditions, there is no least common denominator but rather a standard, which offers "an elevated level of protection, pursuant to Union Law and harmonised with the common Constitutional traditions". On the other hand, setting the European level of protection using the highest national standards would avoid conflicts with national Constitutional Courts, favouring, given the expansive force (vis expansiva) of the Charter, the elevation of the level of protection in other States and other areas not associated with Union Law.

Procedural and extradition legislation play a significant role in the identification of the common tradition. To begin with, in terms of trials in absentia and surrender so that the requested person serves a sentence handed down in absentia, the common European tradition can be located in the European Convention on Extradition, of 13 December 1957, ratified by Spain on 21 April 1982, in which Art. $3^{50}$ lays down that when a Contracting Party requests from another the extradition of a person for the purpose of carrying out a sentence imposed by a decision rendered against him in absentia, the requested Party may refuse to extradite if, in its opinion, the proceedings leading to the judgment did not satisfy the minimum rights of defence recognized as due to everyone charged with a criminal offence. Secondly, Spanish procedural tradition is evident in this regard given that until 1988, trials in absentia were not permitted at all and since then it is allowed but only for offences whose penalty was no greater than one year of prison. This continues to be the case in Spain where trials in absentia are not permitted for trials whose penalty is greater than one year of prison.

Thirdly, common European tradition cannot be the one reflected in the 2009 Framework Decision, nor that laid out in the first draft of the 2002 Framework Decision concerning the European arrest warrant. To that end, the results of the study commissioned by the European Commission from the Institute of European

\footnotetext{
${ }^{48}$ Art 52.4 CFREU establishes that "In so far as this Charter recognizes fundamental rights as they result from the constitutional traditions common to the Member States, those rights shall be interpreted in harmony with those traditions". Similarly see Mangas, A., Carta de Derechos fundamentales, p. 8 39; Izquierdo Sans, C., RDE, 34, 2010, p. 205.

49 Alonso García, R., Sistema jurídico de la Unión Europea, pp. 318 et seq.; von Koen Lenaerts, Die EUGrundrechtecharta: Anwendabarkeit und Auslegung, Europarecht (EuR), 1, 2012, pp. 3 et seqq., 14-15.

${ }^{50}$ Introduced by the Second Additional Protocol to the Convention, of 17 March 1978, ratified by Spain on 18 February 1985. See the Memorandum of the European Council about the judgment in absentia 1998, PC-OC (98) 7.
} 
Studies at Université Libre de Bruxelles ${ }^{51}$ were that there were countries, which expressed their regret at the lack of protection in these cases ${ }^{52}$.

\section{Conditions for the legitimacy of the restriction of the right to a fair process: Art. 52.1 CFREU}

As has been previously mentioned, Art. 52.1 CFREU prohibits the limitation of fundamental rights and thus, beyond the question as to whether the Framework Decision should be included among the valid sources which authorize the limitation of fundamental rights - this matter will not be explored further - the case must be argued for the need and proportionality of the restriction to the right to a fair trial. Within this context, one must make a case which goes beyond merely establishing that the ends of the restriction are legitimate, in addition to necessary and proportional, given that it attempts to improve the pursuit and penalization of serious offences and that it is the protection of fundamental interests of our society and of the individual rights of victims which validates the restriction. With this logical foundation, one could justify any restriction on fundamental rights in criminal matters dealing with the pursuit and penalization of serious offences and the only complimentary argument, which would need to be made concerns the severity of the offence, which causes the limitation of the right. Apart from the vagueness of what the various States consider a serious offence, in the author's opinion, not even in cases of very serious offences does the rule of law admit any limitation on the defendant's rights. For example, a decision substantiated by evidence obtained through torture cannot stand nor can a decision taken based on the retroactive application of legislation. Thus, the starting point for any type of argumentation must be the identification of the red line which one cannot cross, and which, in this case, has been determined by the essential content of the fundamental right, i. e. by the core or set of guarantees whose restriction would devalue the right to such a degree that it would become unrecognizable and incapable of fulfilling the function it serves within the rule of law. To this end, it is worth noting that the Spanish Constitutional Court has set the red line of the identity of the right to a fair trial in the presence of the defendant at the trial. It is only in this way that the defendant becomes the subject of the process - directing the defence and exercising his or her right to self-defence and to the last word - and not a mere object in $\mathrm{it}^{53}$.

\footnotetext{
${ }^{51}$ Analysis of the future of mutual recognition in criminal matters in the European Union, published as Vernimmen-van Tiggelen, G./Surano, L./Weyembergh, A., The future of mutual recognition in criminal matters in the European Union, IEE-Université de Bruxelles, 2009.

52 See Vernimmen-van Tiggelen, G. /Surano, L. /Weyembergh, A., The future of mutual recognition in criminal matters in the European Union, pp. 22, 42, 45.

${ }^{53}$ STC $91 / 2000$, FJ 7, holds that those rights that can be universalized "are inherent to human person, conceived to mean individuals with rights, i. e. free and responsible members of the legal community who deserve this title and not mere objects in the exercise of public authority" and further on FJ 14 affirms that: "Imposing, without neither prior nor posterior hearing or personal defence, penalties which gravely affect those rights which are closely linked to personality, on the basis of accusations which involve reproach of such severity that it is projected over the condition of person, itself, is incompatible with their dignity, more so if it is considered his communicational essence, that as a legal subject, co-responds to the person. This core of legal accusation, and therefore, action and expression of which
} 
Of course, the fact that the Spanish Constitutional Court has located the red line in this way does not mean that there is no room to differ. If one considers, however, that the presence of the defendant at the trial is not an element of the essential content of the right to a fair process, it therefore belongs to the group of limitable guarantees. In any event, to make a case for the legitimacy of limitation, one must argue that a trial in absentia of the defendant is necessary and proportional in order to achieve the legitimate interests of the European Union. In this context, argumentation with regard to the objective of the European Union to achieve a common area of freedom, security and justice would be incomplete. No one doubts that this is a legitimate objective; it is, however, no more than an instrument for achieving other mediate purposes, relative to the protection of the fundamental interests which are protected under the criminal law. Thus, it is not enough to simply pit the need for recognition of judicial decisions in the European Union against limitations on the right to a process with full guarantees, nor can one simply denounce as abusive the protection of a non-present defendant. One should, instead, weigh up whether the protection of fundamental interests of society can be achieved or if it can be achieved to the same or a greater degree in trials in absentia. To put it another way, one must weigh up what is gained in Europe in terms of the prevention and penalization of serious delinquency if we permit the lowest standard of protection, i.e. the restriction on the right to a fair trial in these cases, in comparison with the prevention and penalization of serious delinquency obtained without said restriction on the fundamental right. We must, therefore, ask ourselves what we gain by admitting mutual recognition of judicial decisions handed down in trials in absentia. What is lost is clear: individual freedom, legitimacy in the operation of the system, trust in public authorities which put security before freedom. In the author's opinion, what is gained is precious little. On the one hand, the international detention order, or arrest warrant, has the same effect on the accused person as it does on the sentenced person. In both cases, it impedes their free movement among Member States and therefore, they must live "in hiding". On the other hand, if the individual is not released to the proper jurisdiction, he or she cannot serve the sentence, and therefore neither the retributive effect, nor the individual preventive effect, nor rehabilitation can occur due to the mere fact that the individual was convicted in absentia. Then again, it is possible that, in these cases, the mere sentence in absentia can produce a certain symbolism of a more effective criminal law system (general prevention), albeit this is merely a mirage. The offender remains beyond the reach of the proper jurisdiction and with the same limitations as those suffered if an arrest warrant had been issued in order to try him or her. For that matter, as there are differences in the procedural legislation of Member States, trying an individual in absentia in a State alters the legal title, by virtue of which the arrest warrant has been generated, and this alteration can have negative effects. Let us take a look: if an arrest warrant were issued to Spain for an Italian citizen in order to try him in Italy,

personality consists, would be radically denied if the act of sentencing in absentia closed off all possibilities of directly hearing the accused person for a very serious offence." 
Spain would have no reason to refuse the surrender; on the other hand, if the same citizen had been sentenced in absentia in Italy, Spain could authorize a conditional surrender which would delay and even prevent the process from concluding. From this point of view, and given that the delay of proceedings has a negative effect as to the prevention of the offence, issuing a warrant for the trial of an offence may be a better option than to sentence the individual in absentia and issue the arrest warrant, subsequently, for the fulfilment of the sentence. Meanwhile, at the other end of the scale, we must weigh up that, once the concerned person has been sentenced, albeit in absentia, the sentence has an aggravating effect on successive sentences. This could increase the preventive effects. Once again, however, we must remember that these effects occur only in and from the moment he or she finds himself available to the proper jurisdiction. Moreover, the general preventive effects do not increase if the requested person continues to live beyond the reach of the law. These effects depend, to a great degree, on the efficiency of the criminal prosecution, i. e. the certitude with which the penalty is imposed and thus, as long as the individual continues to live beyond the reach of the law, we can only observe symbolic effects, not real ones. To reach these symbolic effects should not be our priority above the real costs that the rule of law hgas by reducing the guarantees intrinsically linked to the right to a fair trial. Therefore, the restriction on the right to a fair trial is not the ideal measure to achieve the desired objective: improved protection of fundamental interests. It is evident that in order to achieve the desired objective, we must increase police efficiency with regard to the pursuit and capture of individuals and the speed of their surrender order to be tried for the offences committed.

In short, as it is not the accused person, the right holder, who has the burden of proof to justify his absence at the trial, but rather the public authorities who must demonstrate that the restriction on the right is legitimate, neither trials in absentia for serious offences nor the automatic recognition of judicial decisions, which deliver sentences in absentia, pass the test of proportionality for the restriction of the right to a fair trial. There are a number of concerns in terms of whether any real efficiency is gained in the criminal system as well as if there are no other alternatives which have less of an impact on fundamental rights and are more efficient with regard to achieving the purpose of protecting the fundamental interests of society.

\section{Art. 53 CFREU as a general minimum clause}

Another argument to justify the higher Spanish standard can be found in the fact that though secondary European legislation - the 2009 Framework Decision - does not oppose the primary European Law- Arts. 47 II and 48.2 CFREU -, it does not prevent Member States from maintaining a higher standard of the fundamental rights. This can be supported by means of a combined interpretation of the following elements.

First of all, Art. 53 CFREU can be interpreted as a clause, which guarantees the minimum conditions for the rights, recognised therein, similar to other clauses set out in the international conventions on human rights, particularly in the parallel 
clause, Art. 53 ECHR. Among other reasons, the wording of these provisions is quite similar ${ }^{54}$.

Art. 53 ECHR: "Nothing in this Convention shall be construed as limiting or derogating from any of the human rights and fundamental freedoms which may be ensured under the laws of any High Contracting Party or under any other agreement to which it is a party".

Art. 53 CFREU: "Nothing in this Charter shall be interpreted as restricting or adversely affecting human rights and fundamental freedoms as recognized, in their respective fields of application, by Union law and international law and by international agreements to which the Union or all the Member States are party, including the European Convention for the Protection of Human Rights and Fundamental Freedoms, and by the Member States' constitutions".

Beyond the relative differences in the legislation, which refer to both clauses, the significant difference lies in the subsection of Art. 53 CFREU referring to the right recognised "in their respective fields of application". This subsection is open to varied interpretations, one of which has already referred to. It is possible to appreciate that this provision only guarantees that the fundamental rights recognised by Member States must not be limited when not applying Union Law; meanwhile, when applying Union Law, the standard which prevails should be the European standard even though this would imply a reduction in national standards. Additionally, however, one can interpret that this subsection is only attempting to point out that, even though the validity of certain fundamental rights for a determined sphere of application - international conventions or national constitutions - apart from the European sphere, was initially recognised, this does not, presently, prevent the Charter from respecting them in the European sphere, and therefore in the European sphere, these rights are recognised by means of minimums. Thus, irrespective of its wording, the meaning of Art. 53 CFREU is that its content does not cancel out, limit or infringe upon the fundamental rights at their highest national or international standard.

This interpretation best fits with the idea that the European Union lacks competency with regard to fundamental rights and also with the content of Art. 51 CFREU, which would seem redundant if Art. 53 CFREU were interpreted as a guarantor of a common standard for the European framework of competencies. Secondly, this interpretation does not oppose the objective of creating a space of freedom, security and justice in the European Union, but rather frames it in a design in which freedom and justice are not simply the silent partners of security and through which the weight that fundamental rights deserve in the legal framework of the European Union, is balanced out. In this context, as Advocate-General Cruz Villalón in the Conclusions of the I. B. case maintained, the interpretation carried out by the Framework Decisions must take into account all the objectives being

\footnotetext{
${ }^{54}$ This is one of the interpretations recommended by the Constitutional Court in ATC 86/2001, FJ 7 a). As Alonso García, R. warns (Sistema jurídico de la Unión Europea, p. 323), Art. 53 of the Charter does not only refer to protected rights but rather those which are not laid out in the Charter but which are established in the ECHR or in national Constitutions. For example, the right of the convict person to a review of his sentence by a higher tribunal, which was not included in the Charter but that it is recognized on Art. 14 (5) International Covenant on Civil and Political Rights.
} 
sought and not forget that "although mutual recognition is an instrument for strengthening the area of security, freedom and justice, it is equally true that the protection of fundamental rights and freedoms is a precondition which gives legitimacy to the existence and development of this area",55.

Furthermore, this interpretation of Art. II-113 of the Treaty on the European Union, identical to Art. 53 CFREU, as a minimum clause allowed the Spanish Constitutional Court to guarantee the compatibility of the Treaty on the European Union and the Spanish Constitution. Though this is not a definitive argument on the European level, one must take it into consideration as the Constitutional Court warned of the possibility of using the appropriate channels in the case of a discrepancy between the Spanish Constitution and European Law (FJ4). In Declaration 1/2004, of 13 December, the Spanish Constitutional Court held:

"Article II-113 of the Treaty sets forth that none of the provisions in the Charter 'may be interpreted as limiting or detrimental to the human rights and fundamental freedoms recognized, in their respective scope of application, by the legislation of the Union, international law and the international agreements of which the Union and all the Member States are a part, and in particular, the European Agreement for the Protection of Human Rights and Fundamental Freedoms, as well as by the constitutions of the Member states'. Consequently, besides the bases of the Charter of Fundamental Rights in a community of values with the constitutions of the Member States, it is clear that the Charter is conceived, in whatsoever case, as a guarantee of minimums on which the content of each right and freedom may be developed up to the density of content assured in each case by internal legislation." (FJ 6)

"In the unlikely case where, in the ulterior dynamics of the legislation of the European Union, said law is considered irreconcilable with the Spanish Constitution, without the hypothetical excesses of the European legislation with regard to the European Constitution itself being remedied by the appropriate channels set forth therein, in a final instance, the conservation of the sovereignty of the Spanish people and the given supremacy of the Constitution could lead this Court to approach the problems which, in such a case, would arise. Under current circumstances, said problems are considered inexistent through the corresponding constitutional procedures, apart from the fact that the safekeeping of the aforementioned sovereignty is always ultimately assured by Art. I-60 of the Treaty, the actual counterpoint of Art. I-6, which makes it possible to define, in its real dimension, the primacy set forth in the latter, incapable of overcoming the exercise of a waiver, which is reserved for the supreme, sovereign will of the Member States." (FJ 4)

\section{The case law of the European Court of Justice permits the coexis- tence of different standards}

The interpretation carried out here concurs with the evolution of the jurisprudence of the European Court of Justice ${ }^{56}$. On the one hand, the Court of Justice

\footnotetext{
55 See Paragraph 43, Conclusions, Case C-306/09, filed 6 July 2010. Though the I. B. case has given rise to ECJJ, of 21 October 2010, sadly the arguments used in the case have not been reflected in its conclusions in law.

${ }^{56}$ See Alonso García, R., Sistema jurídico de la Unión Europea, pp. 325 y ss.; von Koen Lenaerts, EuR, 1, 2012, pp. 3 et seq., 15 .
} 
has allowed the European standard to exceed that of the Council of Europe ${ }^{57}$. On the other hand, the Court of Justice has also afforded Member States a certain degree of discretion as to the protection of fundamental rights despite the fact that this may, consequently, restrict European freedom, warning that the legitimacy of restriction to European freedom does not require "to correspond to a conception shared by all Member States as regards the precise way in which the fundamental right or legitimate interest in question is to be protected",58.

Moreover, this interpretation does not come into conflict with the jurisprudence of the Court of Justice as per the Kozlowski and Wolzenburg cases. As the Advocate-General Cruz Villalón held in the Conclusions in the I. B. case, said decisions are previous to the entry into force of the Nice Charter, of 1 December 2009, and therefore the provisions of the Charter, including Arts. 52 and 53, set a framework for interpretation of the European legislation that is distinct from the one in which the Kozlowski and Wolzenburg ${ }^{59}$ cases were delivered. Thus, the possibility for conditional surrender of requested persons in cases not explicitly set forth in the Framework Decision, concerning the European arrest warrant, must not be perceived as a matter which has been definitively resolved by means of a negative general rule to be applied in all cases. To put it another way, of the judgements cited, the conclusion that the State can never require a conditional surrender in cases not explicitly laid out in the Framework Decision does not necessarily follow. On the one hand, the failure to mention certain possible restrictions on mutual recognition of judicial decisions, which imply refusal of or conditions to the surrender, may not indicate an express decision, but rather be the result of a legal technical defect; and on the other hand, these omissions may take on a different meaning in light of the new framework for fundamental rights set forth in the Nice Charter" ${ }^{60}$. As ATC 86/2011 reminds us, "according to the reiterated

\footnotetext{
${ }^{57}$ The Okrem $v$. Commission case, of 18 October 1989 (347/87), based on the fact that the right against selfincrimination was not expressly recognized in Art. 6 of the ECHR, the Court of Justice held that a company could not be forced to collaborate with the Administration, answering questions, if said actions implied admitting the existence of an infraction, which burden of proof is the Commission.

${ }^{58}$ The Court of Justice admitted that national authorities may submit companies' searches records to the test of proportionality in accordance with their domestic legislation, which includes the possibility of requiring prior legal authorization, an element which is not required by all States, case Hoechst v. Comission, of 8 July 1999 (C-227/92 P). And more recently in cases Schmidberger, of 12 June 2003 (C-112/00), and Omega of 14 October 2004 (C-36/02). The quotation is from the Omega case, 37 .

${ }^{59}$ In fact in the Kozlowski case (STJUE of 17 July 2008, C-66/08, 43) the question as to the open or closed nature of the grounds for refusal is not clearly reasoned and is only the object of this subsection, and the fact that States possess certain discretion to interpret the grounds for refusal is affirmed in the ECJJ, Grand Chamber, of 6 October 2009, the Wolzenburg case.

${ }^{60}$ In paragraph 44 of the Conclusions Advocate-General Cruz Villalón, I. B. case, C-306/09, filed 6 July 2010 states: "Moreover, the need to interpret the Framework Decision in the light of fundamental rights has become more imperative since the entry into force of the Charter of Fundamental Rights, Article 7 of which covers the right to private and family life. ... Until now the case-law of the Court of Justice on this issue has related very specifically to the free movement of persons but has not involved itself directly in the relationship between this right and judicial cooperation in criminal matters. The fact that the Kozlowski and Wolzenburg judgments preceded the entry into force of the Charter is linked logically to that result. Nevertheless, from 1 December 2009, it is imperative that Articles 4(6) and 5(3) of the Framework Decision should be interpreted in the light of Article 7 of the Charter. This being the case, the narrow interpretation put forward in points 38 to 40 of this Opinion cannot prevail". Additionally, see paragraph 46, "Thus, these last arguments powerfully demonstrate that when the Framework Decision does not expressly refer to the possibility of making execution of a warrant for the execution of a sentence conditional in circumstances such as those in the
} 
jurisprudence of the European Court of Justice, existing acts of secondary European Law must be interpreted in light of fundamental rights as general principles of Union Law but also as they appear set forth in the Charter on Fundamental Rights of the European Union, whose legal status is, pursuant to article 6.1 TEU, identical to those of founding Treaties" 61 . In this context, it worth wondering, as the Constitutional Court has done, whether the Framework Decision allows for conditional surrender ${ }^{62}$. These conditions do not constitute a literal and automatic refusal to surrender, and what is set out in the Framework Decision, is simply that Member States cannot establish a compulsory refusal of surrender.

\section{A different interpretation of the case: the conditions of legitimacy for the tacit waiver of the right to a defence}

Finally, although we have taken the idea, that the analysed case is not one of those which would lead the European Court on Human Rights to declare a violation of the right to a process with full guarantees, as our starting point, it is possible to interpret the events in another manner. One could posit that the Court understood that the requested person had tacitly waived his right to appear on trial and defended himself and that this tacit waiver had been inferred, exclusively, by the concerned person's non-appearance. If this were so, it would be worth considering to what point the pronouncements of the European Court on Human Rights regarding the waiver of the right to appear on trial fit with those concerning adequate forms of notification and awareness of the trial as well as of defence provided by a legal counsellor, a question which has not been clearly resolved in the jurisprudence of Strasbourg. In other words, in this hypothesis, the European Court of Justice has room for interpretation as to the scope of the right to a process with full guarantees without contradicting the jurisprudence of Strasbourg; it could rule on the question concerning whether, in accordance with the right to a defence guaranteed by the European Union in Arts. 47 II and 48.2 CFREU, a violation occurs in cases, such as that under consideration, in which the sentenced person has not expressly waived the right to appear in Court and to exercise his or her right to self-defence but rather a tacit waiver has been deduced from his or her absence at the trial. At the same time, this pronouncement might lead the Court to affirm a contradiction between Art. 4 a.1 of Framework Decision 2002/584/JHA and Arts. 47 II and 48.2 CFREU, as it seems that Art. 4 a.1, points a) and b), allow one to deduce a tacit waiver from the mere fact that the accused has received a notification or from his awareness of the date, time and location of the proceedings.

\footnotetext{
present case, this does not reflect a deliberate legislative decision which is the product of a clear and precise political will. On the contrary, in my view it is more a question of silence due to faulty legislative technique, whose remedy may and must be sought through interpretation, without any need to create a new ground for non-execution".

${ }^{61}$ See SSTJUE of 19 January 2010, Kücükdeveci, (C-555/07), par. 22; of 9 November de 2010, Volker und Markus Schecke y Eifert, (C-92/09), par. 45 y 46; and of 1 March de 2011, Association Belge des Consommateurs Test-Achats and others, (C-236/09), par. 16.

${ }^{62}$ ATC 86/2011, of 9 June, FJ 5, b).
} 


\section{Epilogue}

The response of the European Court of Justice to the questions referred for a preliminary ruling is transcendental for the design of the protection of fundamental rights in Europe; we should, therefore, congratulate the Spanish Constitutional Court for having taken this critical step in this area and for having done so with the depth that the transcendence of these questions deserves. We must now wait for the European Court of Justice to honour what is at stake and take fundamental rights and its role as their protector seriously. To this end, I believe that there are valid arguments for not shutting the door to the possibility that States could maintain and protect a standard of fundamental rights higher than that of the European Union apart from the solution for the case we have considered.

When we deal with the application of fundamental rights in criminal matters, criminal law theorists are at a disadvantage from the outset, as citizens generally consider that the protection of the fundamental rights of offenders is a very unfriendly topic, especially when this protection creates a cost for society. Perhaps the sensitivity of citizens, in the realm of fundamental rights applied in criminal trials, would be different if we, criminal law theorists, were able to transmit to society the idea that these fundamental rights not only protect the offender, but also the citizens, so that public authorities cannot convert them, arbitrarily, into offenders, i. e. through a trial without guarantees. 
